\title{
A Pragmatic Approach to Katherine Mansfield's "The Man without a Temperament"
}

\author{
Pilar Alonso \\ Universidad de Salamanca
}

\begin{abstract}
Katherine Mansfield's "The Man without a Temperament" seems to encourage two opposite types of response among its readers, especially with regard to the role played by the male protagonist. Some readers reject the character with deep contempt, others admire his conduct. The co-existence of these contradictory opinions poses a reception problem. The aim of this paper is to investigate this problem from a pragmatic point of view. The analysis of the language selected and the situational constituents shows how the double response is intrinsically created by the producer's own decisions (conscious or unconscious), and how it may be interpreted as a natural consequence of the reading of the text.
\end{abstract}

\section{Introduction: the pragmatic-communicative level}

In 1980 Antony Alpers published his second biography of Katherine Mansfield. In it he included a brief footnote to the text claiming that Robert Salesby, the protagonist of Mansfield's short story "The Man without a Temperament," was based on John Middleton Murry, Mansfield's husband:

Not a few have supposed-the present author being among them once-that this acute portrayal of a man whose wife is hopelessly ill on the Riviera was a picture of Murry himself (whether consciously so or not), and a hostile one. That is not at all what he thought. After reading the author's previous biography in 1953 he said that its comment struck him as "a quite fantastic misreading of the story," and he added: "If ever a character was drawn with loving admiration, Salesby was. I should be very well content to go down to posterity as his original." (Alper 305)

The foundation for this narrative-biographic parallel must be found in the similiraty between reality and the events narrated in "The Man without a Temperament" and reality. 
In the story, the female protagonist suffers from a fatal illness. Her doctor strongly recommends that she should leave England accompanied by her husband in search of a warmer climate. When Mansfield wrote "The Man without a Temperament" in Ospedaletti, Italy, in 1920, she was badly affected by tuberculosis, a disease which was to result in her death three years later. During her illness, Mansfield's curative trips to the Continent were constant. Sometimes Middleton Murry accompanied her.

In theory, we should not attach much importance to Alpers and Murry's words. They express nothing but the opposite opinions of two persons about a fictional character, even if both men have, for different reasons, expert knowledge of Mansfield's life and work, and the character is the protagonist of one of the author's most enigmatic and best constructed short stories. However, it is an interesting fact that the division of opinions ("hostile" vs. "loving admiration") recurs again and again among readers in their response to the character. I have often used "The Man without a Temperament" in my graduate courses on Literary Discourse Analysis and both judgements always appear: there are those who think that Salesby's portrait is drawn with amability and understanding, while others believe his attitude towards his wife's misfortune is cold and insensitive, and hence reprovable.

The situation poses a pragmatic problem. On the one hand, it involves conditions of reception: the readers' divided attitude towards the textual contents. On the other, it concerns aspects related to production itself, that is, which of the two positions would be more faithful to the writer's own feelings or intention. From a literary point of view this may be irrelevant. From a pragmatic perspective the issue becomes a challenge.

In his article "Text and Sentence in Discourse Planning" de Beaugrande defends a broad vision of pragmatics based on the following categories: (1) the producer's intention and motivation, (2) the discursive action or macro-speech act realized in the text, (3) the effect the textual contents has on the receiver. Accepting de Beaugrande's view implies understanding pragmatics as "the investigation of correlations between the systemic factors of a communicative situation - e.g. intentions, needs, plans, goals, knowledge, beliefs, attitudes, codes of behavior, past experience-and the actual manifestations of language" (468). If we are willing to assume these principles, and also that, among its other possible functions, the literary text is a linguistic unit with the capacity to establish communicative interaction between producer and receiver, then, a pragmatic analysis of the literary text would provide the means to obtain relevant data concerning the participants in the communicative act and the peculiarities of their interaction with the text (de Beaugrande Critical Discourse 7; Alonso "The Semantics and Pragmatics" 320). Given the specific conditions of literary communication (e.g. absence of the producer), these pragmatic aspects: intention, motivation, action, and effect, are accessible to the analyst only through detailed observation of the linguistic components of the text.

Jon $\mathrm{K}$. Adams confirms the importance of language analysis on the evaluation of the pragmatic constituents of a literary text, stating that the fiction writer is not the direct agent of communication. On the contrary, the author communicates indirectly through the linguistic material selected for his/her narrator and characters: 
... the only rhetorical method that would allow the writer to manipulate his fictional speaker from within the communicative context seems to be through selection, because selection of material does not in itself require the writer to be a speaker. (Pragmatics and Fiction 61)

Thus, an analysis of the language selected becomes first hand material for the reader in searching for the writer's possible intentions. In Mansfield's case this procedure is more accurate, if one might say so, because we know of the meticulousness with which she chose each and every word, even the sounds, of her literary creations. Mansfield herself spoke about the process of language selection as her "method" in her comments on "Miss Brill," a short story published in 1920, just eight months after "The Man without a Temperament." These are her words in a letter to Richard Murry, dated January 17, 1921:

It's a very queer thing how craft comes into writing. I mean down to details. Par exemple, In "Miss Brill" I choose not only the length of every sentence, but even the sound of every sentence. I choose the rise and fall of every paragraph to fit her on that day at that very moment. After I'd written it I read it aloud-numbers of times-just as one could play over a musical composition-trying to get it nearer and nearer to the expression of Miss Brill—until it fitted her.

Don't think I'm vain about the little sketch. It's only the method I wanted to explain. I often wonder whether other writers do the same-if a thing has really come off it seems to me there musn't be one single word out of place, or one word that could be taken out. That's how I AIM at writing. It will take some time to get anywhere near there. (Mansfield, Letters and Journals 213)

It shouldn't be forgotten that another source of information, this time direct, is provided by those linguistic items placed outside the boundaries of the fiction world. The title, notes, epilogues, etc. that precede or follow the actual text belong to the writer as speaker, and function, for the analyst, as important evidence of the writer's intentionality (Alonso "The Literary Text Type" 71).

From all this, we can conclude that both the analysis of the language selected by Mansfield for her narrator and her characters, and the consideration of the title she chose for her story will prove valuable paths for approaching her own attitude towards the text. By analysing these elements we will try to discover why "The Man without a Temperament" gives rise to that double response among its readers. I could anticipate the hypothesis that this is so, precisely because the two contradictory positions of sympathy and rejection are inextricably linked in the language of the text. If we make use of that pragmatic intersection which, according to Ricouer, exists between the narrative world and the real world, we might find the origin of the narrative conflict in the author's own state of mind at the moment of writing: her confusion, agony, and indecissiveness (Ricouer $D u$ texte a l'action). The fact that Mansfield chose to write about a subject deeply related to her extreme situation supports this view (see Appendix). 


\section{The language selection}

A first approach to the language used by the speakers in "The Man without a Temperament" (narrator and characters) leads us to distinguish four textual worlds, each with its own characteristics. The order in which we enumerate them is the order in which they appear: (1) the narrator, (2) the English-speaking characters, (3) Salesby, the protagonist, and his wife, (4) the characters native to the place where the action occurs. At a global level, they all interact; but, locally, Mansfield has made them totally autonomous. Cohesion is achieved through the narrative voice, and a trait common to all groups involved is their attitude towards Salesby, the protagonist and centre of the narration. We have direct evidence of this character's crucial role when we investigate the title of the story. Originally it was titled "The Exile" (Alpers 305). The change from "The Exile" to "The Man without a Temperament" is significant because it reveals how Mansfield moved the focus of attention from the situation to the male protagonist. The first title involved both the male and female characters and their very negative circumstances. The second not only presupposes Robert Salesby's importance, it also passes judgement on his character.

A brief analysis of the final title shows how it incorporates the two contradictory elements mentioned above. On the one hand, the protagonist is made a prototype by using the generic "The Man"; on the other, he is deprived of one of the most essential features of a human being: "without a Temperament." According to the dictionary, "your temperament is your basic nature, especially as it is shown in the way that you react to situations or to other people" (Collins Cobuild). This is how the title-which in this case is the only direct link the reader can establish with the author-not only imposes attention on a character, but also marks him negatively. In view of this, it does not seem arbitrary that Salesby and his attitude towards the narrative situation soon dominate the discussion. The conflicting components are implicit in the title which functions efficiently as macrostructure of the text (Brown and Yule, Discourse Analysis 71-73). From the very beginning, the author places the reader in the middle of the problem we have recognized as pragmatic. The next step must be to confirm if this early interpretation actually matches the information in the story.

As a matter of fact, this contrast exists everywhere in the narration. Each narrative world receives a specific linguistic treatment. The author uses language masterly to indirectly emphasize the distance which separates them. On one side there are the Englishspeaking characters, on the other, the local characters. In contrast with them all Mansfield creates the Salesbys, who by no means can be treated as a single unit. The clues are obtained when we compare the distinct worlds and analyse their differences.

\section{The narrator}

The narrator is omnipresent and decissive in the organization of the textual structure. The relation she holds with all characters is impartial, respectful, and detached. The protagonist and his wife are always impersonally referred to as "he" and "she." The secondary characters are given labels and converted into prototypes, as in the title. Thus we have "the 
Two Topknots," "the American Woman," "the servant girl," "the Honey Moon Couple," "the General and Countess," and "the driver." It is interesting to note how the Englishspeaking characters are capitalized, while the locals, of a lower social rank, are not.

From the very first sentence on ("He stood at the hall door ... his glance travelled coolly deliberately ..."162), the narrative point of view walks side by side with the protagonist. Only on two occasions does it move away from him, for a very short span, to merge, first, with one of the secondary characters: "The American Woman" (162, 11. 14-17), then, with Mrs. Salesby (168, Il.12-16). In both cases, it turns to free indirect speech (stream of consciousness) to allow the reader into the characters' mind. Accordingly, and excepting the dialogues, which we will study associated to the different characters, the story uses third person narration to relate in full detail all that surrounds the protagonist, what he sees or should see if his attitude were not aloof and insensitive to any reality different from his and his wife's. This aloofness is marked in the story in two different ways: linguistically, by the recurrent use of negative constructions to describe aspects of the protagonist ("But he saw nothing" [162], "But he gave no sign" [163], "No answer" [163], "He wasn't there" [166], etc.); pragmatically, by a total absence of communicative interaction with anybody of the protagonist's present moment but his wife. The negative treatment consistently given to the character reinforces the idea activated by the title. These are elements which gradually shape and influence the reader's response.

It is important to note, however, that the narrative voice acquires different qualities in different situations. The author modifies the tone of the narration, its rhythm, and the selection of language to suit the characters and the categories they represent. The contrast created provides the necessary information in an indirect way: nothing is spelled out. The narrator carefully draws a first sketch of every character (or every two characters when they are a couple: "The Two Topknots," "The Honey Moon Couple"), and the features chosen for each composition remain unaltered throughout the narration. Let's see how it works with "The Honey Moon Couple." This is how they are introduced in the story:

Half striding, half running, carrying a basket between them and rods and lines, they came up the drive, up the shallow steps.

"My! have you been out fishing?" cried the American Woman.

They were out of breath, they panted: "Yes, yes we have been out in a little boat all day ..."

They were a very dark young couple-black hair, olive skin, brilliant eyes and teeth. He was dressed "English fashion" in a flannel jacket, white trousers and shoes. Round his neck he wore a silk scarf; his head with his hair brushed back, was bare. And he kept mopping his forehead, rubbing his hands with a brilliant handkerchief. Her white skirt had a patch of wet; her neck and throat were stained a deep pink. When she lifted her arms big half-hoops of perspiration showed under her arm-pits; her hair clung in wet curls to her cheeks. She looked as though her young husband had been dipping her in the sea and fishing her out again to dry in the sun and then-in with her again-all day.... (166)

The language selected to represent what is expected of these typical newlyweds consists, first, of a recurrent use of duals and double enumeration ("half striding, half running," 
"between them," "rods and lines," "up the drive, up the shallow steps," "they were out of breath, they panted," "Yes, yes"); second, of action verbs in the progressive aspect ("striding," "running," “carrying," "fishing," “mopping," "rubbing," "dipping," "fishing"). Mansfield introduces both devices to achieve the rythmic swinging effect with which she marks the couple.

But the function assigned to "The Honey Moon Couple" in the story is not limited to their presence in the well-known literary world of English-speaking visitors to warm Mediterranean countries, a genre certainly quite popular at the time. Their healthy and youthful appearance, their tan, their feeling of happy exhaustion after so much physical activity are used by the writer to stress the differences between the young couple and the Salesbys. Actually, the language chosen for "The Honey Moon Couple" is similar to the narrative mode applied to Salesby when he is alone, either in the present time of the narration or in the flashbacks which take him back to his old London routine. But the contrast notably increases when the style used for "The Honey Moon Couple" is compared with the treatment both Salesbys receive as a couple. It is then that the heavy burden of the wife's disease marks both characters. The slowness of her movements, her extreme pallor turns her husband's vitality into impervious rigidity. This is what earns him a reproachful attitude from characters and readers alike. Let's see now how the technique of similarities and contrasts works.

When the story begins Salesby, deep in thought, awaits his wife's arrival. "The American Woman" and the "Two Topknots" look at him astonished and sceptical:

The other tables were empty. A glance passed between the American and the Topknots. She gave a foreign little shrug, they waved an understanding biscuit. But he saw nothing. Now he was still, now from his eyes you saw he listened. "Hoo-e-zip-zoo-oo!" sounded the lift. The iron cage clanged open. Light dragging steps sounded across the hall, coming towards him. A hand, like a leaf, fell on his shoulder. A soft voice said: "Let's go and sit over there-where we can see the drive. The trees are so lovely." And he moved forward with the hand still on his shoulder, and the light, dragging steps beside his. He pulled out a chair and she sank into it, slowly leaning her head against her back, her arms falling along the sides.

"Won't you bring the other up closer? It's such miles away." But he did not move. $(162-63)$

This excerpt shows Salesby's strange detachment from all the other characters, who, in return, look at him with unmistakeable contempt ("A glance passed between the American and the Topknots. She gave a foreign little shrug, they waved an understanding biscuit"). It also shows the attentive, but cold, expectation with which the protagonist meets his wife. And, most of all, it displays the extreme care with which the language used to describe Mrs. Salesby's entrance is selected: the lift is an "iron cage," the recurrent alliteration of the "l" and " $\mathrm{s}$ " sounds mark her with sad and poetic weakness ("Light dragging steps sounded across the hall ... A hand, like a leaf, fell on his shoulder. A soft voice said: 'Let's go and sit over there ... The trees are so lovely ...' the hand still on his shoulder, and the light, dragging steps beside his ... she sank into it, slowly leaning her head ... 
her arms falling along the sides... 'It's such miles away"). These features will be sustained throughout the story so consistently that they become disquieting.

In this way, the writer creates an eloquent semantic field around Mrs. Salesby, which activates the reader's curiosity towards her personality. Mansfield does not reveal how desperate her situation is until the very end of the story (see the last flashback: "In his study. Late summer ... " [173-74]). Before, she only suggests, thus allowing the reader to infer but never confirm the real state of things. This absence of definition early in the text causes ambiguity to which the reader reacts in many ways. There may be sympathy towards such a fragile character, or repulsion when the tyranny which she apparently imposes on her caring husband is considered. Another possible response is a strong dislike of the husband, because, even if he is caring, he is also distant, even hostile. Contrast becomes relevant again in the following scene, when Salesby momentarily leaves his wife alone, and goes to their room to get the shawl she has forgotten upstairs:

\begin{abstract}
"Where's your shawl?" he asked.
"Oh!" She gave a little groan of dismay. "How silly I am, I've left it upstairs on the bed. Never mind. Please don't go for it. I shan't want it, I know I shan't".

"You'd better have it." And he turned and swiftly crossed the verandah into the dim hall with its scarlet plush and gilt furniture-conjuror's furniture-its Notice of Services at the English Church, its green baize board with the unclaimed letters climbing the black lattice, huge 'Presentation' clock that struck the hours at the half hours, bundles of sticks and umbrellas and sunshades in the clasp of a brown wooden bear, past the two crippled palms, two ancient beggars at the foot of the staircase, up the marble stairs three at a time, past the life size group on the landing of two stout peasant children with their marble pinnies full of marble grapes, and along the corridor, with its piled-up wreckage of old tin boxes, leather trunks, canvas holdalls, to their room. (163)
\end{abstract}

The last paragraph is a long sentence which signals through syntax the differences that exist between the true Salesby and the Salesby trapped in his wife's sickness. As soon as he goes away from her, the rhythm changes ("he turned and swiftly crossed the verandah"), he climbs the stairs rapidly, with surprising agility, and youthful impatience ("past ... up ... past ... three at a time"). Now the style reminds the reader of "the Honey Moon Couple" ("they came up the drive, up the shallow steps" [166]). Mansfield will use this device for Salesby whenever he is alone. For example, when he leaves his wife to go for a walk ("On—on-past the finest villas ... past the public gardens ..." [169]); or in the second flashback when he remembers going back home in London ("Over the gate, across a field, over the stile, into the lane, swinging along in the drifting rain and dusk" [170]). These differences are meticulously built into the narration with no explicit explanation. The result is that Salesby's double image confuses the reader, who is forced to question his nature. This is how the pragmatic difficulty we have been tracing is created. The contradictions within the protagonist are reinforced by two external factors: first, the very negative opinion the English-speaking characters have of him, and, second, his wife's loving admiration. We will discuss this in the following sections. 


\section{The English-speaking characters}

The narrator introduces the English-speaking characters always as components of a situation which has the protagonist at its centre. Except for "The Honey Moon Couple," none of them is given autonomy of action. On the contrary, they are treated as if they were objects in a still life. This effect is achieved by the recurrent use of place and frequency adverbs, as in the following quotes: "Over in the corner sat the Two Topknots, drinking a decoction they always drank at this hour" (162); "The American Woman sat where she always sat against the glass wall" (162); "A carriage came bowling along driving towards the Excelsior. In it sat the General and Countess, they had been for his daily airing" (169).

The characters are drawn static and negative, fairly umpleasant. They become liveless types who are made repugnant to the reader. The feeling they provoke is not so much of uneasiness or strangeness, as with the protagonist, but of real disgust. For instance, "The Two Topknots" drink a "decoction" described as "something whitish, greyish," and "their two coils of knitting" are compared to "two snakes." Another good example is the creeper that grows against the glass wall. On page 167, the narrator describes this plant as "a great gaudy creeper, orange splashed with jet, sprawled against the wall." But the first vision the reader has been given of it is an upsetting image filtred through the distorted mind of "The American Woman." For "The American Woman," the plant is "a great creeping thing with wide open purple eyes that pressed-that flattened itself against the glass hungrily watching her. .." (162). "The General and Countess" do not escape Mansfield's cruel treament either. In their first narrative encounter with the protagonist-and the reader: "the Countess . . . just had time to nudge the General" and "said spitefully," while "The General gave a loud caw and refused to look" (169). Mansfield's technique of contrast also serves to call the reader's attention towards these negative aspects. While the English-speaking characters are motionless ("sat"/"always" [162]), animalized ("caw" [169, 172]), rude ("picking her ear with a knitting needle" [166], "darted out," "bawl" [171]), irrational ("a great creeping thing... hungrily watching her" [162]), the objects, the sculptures are treated much more gently, almost as if they were human ("the life-size group on the landing of two stout peasant children with their marble pinnies full of marble grapes" [163]).

These characteristics are a constant with the English-speaking characters, whose role is to provide a typical idiosyncratic background to the central situation. Also peculiar to them is the very negative opinion they all have of Salesby. We find an example in the way "the American Woman" and "the Two Topknots" react when the protagonist is caring for his invalid wife:

"Will you be warm enough?"

"Oh, quite."

"Sure?"

"Well," she put her hand on his arm "perhaps"-and gave his arm the faintest pressure- "it's not upstairs, it's only in the hall-perhaps you'd get me my cape. Hanging up." 
He came back with it and she bent her small head while he dropped it on her shoulders. Then very stiff, he offered her his arm. She bowed sweetly to the people of the verandah while he just covered a yawn, and they went down the steps together.

"Vous avez voo ça!" said the American Woman.

"He is not a man," said the Two Topknots, "he is an ox. I say to my sister in the morning and at night when we are in bed, I tell her-No man is he, but an ox!" (167)

The judgement is cruel. Just like the author uses the narrator to dehumanize these Englishspeaking characters in a clear sign of hostility towards them, they, in return, revenge themselves on the protagonist, depriving him of both his human rank and his essence ("No man is he-but an ox!"). The relation between this criticism and the title of the story: "The Man without a Temperament," is evident. It is possible to infer from this coincidence that the writer has chosen for her title the image the protagonist projects to these specific characters, with whom he should be friends (they speak his language and belong to his social class), but to whom he is actually incompatible.

Once more, Mansfield selects the language carefully enough to leave no doubt about Salesby's responsibility in the situation: while his wife "bowed sweetly to the people of the verandah," the protagonist "just covered a yawn." Thus, the idea of opposition is reinforced. And these are not the only elements which provoke divided opinions. The beginning of the quote above is another source of disagreement: Salesby kindly offers to get his wife her cape, but then "very stiff, he offered her his arm." The analysis shows that there is conflict at the very heart of the story.

\section{The Salesbys}

Grounds for contradiction also exist in those narrative moments in which all attention focuses on interaction between the Salesbys. The fragments cited so far have shown that they are an affectionate couple. Despite his cold behaviour, Salesby is attentive and cares for his wife. There are other scenes in the text which allow us to go further. For example, the first flashback offers the reader a glimpse of their life in London:

... Millie with the bacon. "Oh if you please, sir, there's two little boys come as they will do the steps and front for a shilling, shall I let them?" ... And then flying lightly, lightly down the stairs-Jinnie. "Oh Robert, isn't it wonderful! Oh what a pity it has to melt. Where's the pussy-wee?" "I'll get him from Millie"... "Millie, you might just hand me up the kitten if you've got him down there." "Very good, sir." He feels the little beating heart under his hand. "Come on, old chap, your missus wants you." "Oh Robert, do show him the snow-his first snow...." (165)

It is possible to recognize the Salesbys in this scene. Significantly, here Mrs. Salesby intimately becomes Jinnie. This only happens in the first and second flashbacks (the second is on 170), not in the last one where the severity of Mrs. Salesby's illness is revealed (173-74). In this simple way, the writer broadens the reader's view. The name "Jinnie" brings into the story possitive connotations of happier times, of health and 
normality. The language chosen for Mrs. Salesby is exactly the same as in the rest of the text: alliteration ("lightly, lightly"), emphatic exclamations ("Oh Robert, isn't it wonderful!," "Oh Robert, do show him the snow"). However, there is a remarkable difference in the description of her movements: Jinnie appears "flying lightly, lightly down the stairs," while "light dragging steps" had formerly introduced Mrs. Salesby (163). After reading this excerpt, Mrs. Salesby seems to be Jinnie's vanishing shadow, but Mr. Salesby is not even as much as a shadow.

At home, in London, Robert gives a totally different impression. He talks to Millie, the maid, and we must remember this never happens in the Pension Villa Excelsior with the girl who is doing their room (163), or with Antonio, the waiter (164), or with any of the other characters. In London he sounds relaxed, sensitive ("he feels the little beating heart under his hand"), as opposed to the stiff coldness he exhibits for the most part of the story. However, there is a high degree of continuity in the way Mansfield introduces this new contrast in the protagonist. To begin with, while Salesby never calls his wife Jinnie, she repeatedly uses Robert to address her husband. Therefore, when the narrator talks about Robert in the flashbacks, the reader is not surprised. This is not the case with Jinnie, where the reader must investigate the language, the choice of words, Jinnie's personal style, to make sure that she and Mrs. Salesby are actually the same person. Furthermore, the present Salesby shows traits of the more sensitive Robert. For example, in the following dialogue:

She turned to him and smiled "You do know what nutmegs smell like—do you Robert?"

And he smiled back at her. "Now how am I going to prove to you that I do?" (164)

Having to understand the many contradictory facets of Salesby is already a challenge for the reader, one further complication is his wife's unconditional love for him. Mansfield uses the most perturbing episode in the story to make this clear. The Salesby walk across the garden and meet three little girls playing in two tubs, their dresses above their waist, their little drawers on the bush:

They screamed, their hair fell over their faces, they splashed one another. But suddenly, the smallest, who had a tub to herself, glanced up and saw who was looking. For a moment she seemed overcome with terror, then clumsily she struggled and strained out of her tub, and still holding her clothes above her waist, "The Englishman! The Englishman!" she shrieked and fled away to hide. Shrieking and screaming the other two followed her. In a moment they were gone; in a moment there was nothing but the two brimming tubs and their little drawers on the bush.

"How-very-extraordinary!" said she. "What made them so frightened? Surely they were much too young to..." She looked up at him. She thought he looked pale--but wonderfully handsome with that great tropical tree behind him with its long spiked horns.

For a moment he did not answer. Then he met her glance, and smiling his slow smile, “Très rum!" said he.

Très rum! Oh, she felt quite faint. Oh why should she love him so much just because he said a thing like that. Très rum! That was Robert all over. Nobody else but Robert 
could ever say such a thing. To be so wonderful, so brilliant, so learned, and then to say in that queer, boyish voice ... She could have wept. (167-68)

There is dramatic contrast between the terror the girls feel ("overcome with terror," "clumsily ... struggled and strained," "shrieked and fled away to hide," "shrieking and screaming") and Mrs. Salesby's admiration for her husband ("why should she love him so much"). This leads once more to the activation of contradictory opinions. Obviously, the reader does not profess the same admiration, and the clever combination of words ("Très rum") does not suffice to erase from his/her memory the disturbing effect of this scene. Not even Mansfield seems to have taken the wife's side, because she constructs the passage in an intentionally ambiguous way. The same is true of the narrator, who, at that precise moment, chooses to enter the woman's thoughts (free indirect style) instead of Salesby's, in spite of her loyalty to him. Only Mrs. Salesby seems to have no doubts.

\section{The local characters}

The last textual world in "The Man without a Temperament" belongs to the secondary characters native to the place where the action develops. They form a weak and limited group, but their presence is significant beyond the local colour they contribute to the story. The characteristic common to all these characters is that they are drawn as singular prototypes. Except for the waiter, Antonio, who speaks with Mrs. Salesby and receives a name, the others are just labelled: "the servant girl," "the driver," etc. In this way they become representatives of their class, as occurs with the English speakers. But, unlike the latter, the former are not capitalized, they are not upgraded to convert them into "literary prototypes" (see section 8 ). On the contrary, they stay unimportant everyday characters, full of life, and totally satisfactory in their various roles.

Their portraits are vividly drawn. For example, "the servant girl" has "small impudent eyes," and addresses Salesby as she would any other foreigner: with irony and in French (the writer uses italics, indicating that it is not her native tongue: "Vous desirez, monsieur?' mocked the servant girl" [163]). Meanwhile, Antonio, the waiter, puts on a mask of servile amability ("grinned Antonio") to speak to Mrs. Salesby (he addresses her as "Signora" and she calls him "Noble Antonio"), and takes it off as soon as he backs away ("Antonio wheeled sharply, stiffened, the grin went out of his face" [164]). They all respond to narration according to their own peculiar experiences: The little girls feel terror (167-68), the driver shows kind indifference (169). Mr. Queet, although not a native of this world, always acts as manager in his role of director of the Pension Villa Excelsior, a typical hotel for tourists and foreign residents on the Continent.

The way in which the local characters refer to the protagonist provides another piece of interesting information. Except for those who work in the hotel (the waiter, the servant girl, and the manager), the others (the driver and the girls) talk about Salesby as "The Englishman." This permits the author to place Salesby on a level with "The American Woman," "The Two Topknots," "The Honey Moon Couple," and "The General and Countess." Mansfield typifies him and turns him into yet another inhabitant of the literary 
universe she is trying to evoke. This is how the reader experiences a more distant view of Salesby, through the eyes of those characters who do not know him, who do not speak his language, and who identify him by reference to his nationality, the most superficial trait of his personality. Thus, the approach to the protagonist follows a pattern of concentric circles where he is the centre, his wife and her situation are beside him. Those who share his language, but do not understand him constitute the third cicle. The outer circle belongs to those characters who see him as yet another foreigner.

\section{The writer, the reader, and the character}

On these grounds, we can assert that the protagonist projects multiple and contradictory images. The three flashbacks in the text help clarify the circumstances which sorround the Salesby. The author gives an advantage to the reader over the secondary characters who lack this information. By now the reader knows that it is the situation which determines.the protagonists' behaviour (not in vain, the first title given to the story was "The Exile"); but its influence is not sufficient to explain everything. Not even the last part of the story-when Salesby recalls the day the doctor told him about his wife's severe condition and recommended he should accompany her in her remedial trip, and she explicitly stated her need of him - encourages the reader to decide whether he approves of the protagonist or not.

The story ends with Salesby giving his wife assistance one more time. She asks him: "do you mind awfully being out here with me?" Salesby answers this crucial question affectionately: "He bends down. He kisses her. He tucks her in, he smooths the pillow." When he finishes, in a new paragraph: “'Rot!' he whispers” (174). Interpreting these final words is by no means a one way road. What is Salesby qualifying as "rot"? His wife's condition, her words, the exile that has been imposed on him? All options are open to the reader. It will depend on the relationship s/he has established with the protagonist. This relationship may be one of empathy, dislike, or a mixture of both if ambiguity has finally prevailed. If we think of the language selected, and the narrative devices used by the writer, we can say that, for Mansfield, ambiguity triumphs. The various contradictions analysed so far favour this view. Let's just remember the more striking ones: (1) Mansfield abandons the protagonist in the most shocking episode of the story, the episode with the girls, (2) she chooses for the story the title which reflects the most hostile point of view, (3) she painstakingly describes Salesby's positive side, in his relation with his wife (168, 173), and very especially in the flashbacks.

Looking back, we see that the narration opens with a gesture of the protagonist which the reader interprets as a sign of doubt: "He stood at the hall door turning the ring, turning the heavy signet ring upon his little finger." It is not an arbitrary sign, because it recurs several times in the story (162 [twice], 164, 171, 172). To make matters more complicated, at the end, it is the wife who turns the ring-just before she asks the crucial question: "Give me your hand.' She turns his signet ring" (174). The feelings of doubt the protagonists share extend to the other participants in the literary interaction. There seems to be no other way to solve the problem but personal choice. 
Actually, the reader's doubt, when s/he faces such a complex text, is the doubt the author has tried to create by showing all the angles of such a tragic situation. These angles are all embodied in the protagonist, and represented in his many names. For his wife, the protagonist is dear Robert; for the hotel employees, he is cold Mr. Salesby; for the English speakers, he is the contemptible "Man without a Temperament"; for the driver he is a foreigner, and for the girls a frightening being, although all four call him "The English Man." At the end of the story, in her dreams, his wife calls him "Boogles" (174). This is an affectionate name which connects with biographic data (see Appendix). Each name activates different images, some of them quite incompatible. In a short story of 12 odd pages, the protagonist receives too many names and presents too many faces. Not surprisingly the reader questions his nature.

\section{Brief notes on the pragmatic-institutional level}

So far we have analysed aspects which belong to the pragmatic-communicative level. That is to say, aspects related to the differences and coincidences found in the readers' reactions to the story, and their correspondence with certain characteristics of the text. This is the basic pragmatic level which the literary text shares with all other types of texts (Alonso, "The Semantics and Pragmatics"). But there is also the pragmatic-ritual or institutionalized function, which is specific to the literary text. According to van Dijk, these properties of the literary text "are socially bound: they depend on the rules, conventions, norms, values and other properties of a culture or community" (Studies in the Pragmatics 247). At this level, the text acquires its quality not so much from its thematic or contextual components, but from the intertextual relations it establishes with other texts which belong to the same literary background. Here, the most important features are the innovations the text may introduce, and the impact it may have on the community.

In the institutional sense, "The Man without a Temperament" is innovative and surprising. Katherine Mansfield uses a well-known literary universe. The world she recreates was fully fashionable in the literature of her time: Henry James, E. M. Forster, Edith Wharton provide good examples. In their novels, these writers explored the ways and values of the American visitors in Europe, of the Europeans in America, and of the British on the Continent. There is evidence that Mansfield had read James' work, and she knew E. M. Forster very well, both as a person and as a writer (see Alpers 255, 294-95). Mansfield makes use of the literary atmosphere shared by these writers to create "The Man without a Temperament," but she does not follow their tradition. She inverts the terms, and achieves a unique effect.

Mansfield introduces a series of drastic changes in the framework which is peculiar to this literary school. These changes should be easily noticed by a reader familiar with this type of text. First, she reduces the characters who, elsewhere, are the protagonists of universal dramas to mere stereotypes. With a careful selection of vocabulary, a set of labels, and capital letters, she converts them into static inhabitants of a conventional background, immutable observers whose only role is to pass ignorant and insensitive judgement on Salesby's behaviour. Second, she chooses as protagonists two characters 
who could be typical if they were not trapped in an extreme situation, and haunted by death. These conditions are extraordinary for this type of text. Furthermore, contrary to expectations, the problems presented in "The Man without a Temperament" have nothing to do with the usual subjects: cultural shock, or extravagant social behaviour, although both pervade the action, personified in the different characters, and distorted by the writer's singular vision. Neither is death the moral which follows improper social behaviour, as it was, for instance, in Henry James' Daisy Miller. Just the opposite, it is a personal tragedy, which causes fear, and a million doubts. The analysis has shown that these doubts are essential parts of the language and the structure of the story, which the reader absorbs perhaps unconsciously. This is why the reading process is so complex, and interpretation so controversial.

\section{Conclusion}

"The Man without a Temperament" is a unique literary work both at the communicative and institutional levels. With her characteristic style, Mansfield distributes the information in a way that surprises the reader, for there are too many hidden motives too soon. All the clues are given in the first two pages, but the reader is unable to puzzle out the answer. The story has been constructed with so much care and so much control of resources ("you know how I choose my words; they can't be changed" [Mansfield, Letters and Journals 143]) that one single reading may take the reader very far away from the author's plan. The text is full of signs which are markedly indefinite (for example the title). These signs become meaningful only when they are recovered. There is no evolution, only disclosure.

At the beginning, the reader may not wait to finish reading to interpret these signs, especially because $\mathrm{s} /$ he is not aware of the importance most of them have for the global meaning of the text. For Mansfield the signs are macrostructural, for the reader they are local. As a result, the reader's reaction may be very subjective because, when s/he attempts an interpretation, s/he lacks the clues. Only if the totality of the text is considered, do the writer and reader's attitudes approach. This is how Mansfield provides her narration with strong mechanisms of cohesion and coherence, while maintaining all expectations. The analysis of the primary pragmatic components: intention, action, and effect, demonstrates that the confusion is not arbitrary, but an essential constituent of the text. The consideration of the pragmatic-institutional aspects from an intertextual perspective allows us to appreciate the importance of Mansfield's contribution to this literary genre.

\section{Works Cited}

Alonso, Pilar. "The Literary Text Type: Notes on a Method of Analysis Based on Text Linguistics and a Practical Application to Katherine Mansfield's 'The Garden Party." Atlantis 13 (1991): 65-92. 
. "The Semantics and Pragmatics of Literary Texts." Actas de XVI Congreso de AEDEAN.

Ed. J. M. Ruiz, P. Abad, J. M. Barrio. Valladolid: Secretariado de Publicaciones de la Universidad de Valladolid, 1994. 319-324.

Alpers, Antony. The Life of Katherine Mansfield. Oxford: Oxford UP, 1980.

Beaugrande, Robert de. Critical Discourse. Norwood: Ablex, 1988.

"Text and Sentence in Discourse Planning." Text vs. Sentence: Basic Questions of Text

Linguistics. Ed. János S. Petöfi. Hamburg: Buske, 1979. 1: 467-494.

Brown, Gillian, and George Yule. Discourse Analysis. Cambridge: Cambridge UP, 1983.

Mansfield, Katherine. Letters and Journals. Ed. C. K. Stead. Harmondsworth: Penguin, 1977.

"The Man without a Temperament." 1920. Katherine Mansfield: Short Stories. Sel. and

intr. Claire Tomalin. London and Melbourne: Dent, 1983. 162-174.

Ricoeur, Paul. Du texte a l'action: essais d' hermeneutique II. Paris: Seuil/Esprit, 1986.

Dijk, Teun A. van. Studies in the Pragmatics of Discourse. The Hague: Mouton, 1981.

\section{Appendix}

This is an excerpt of the Chronology included in Alpers' biography (414). We can appreciate the similarity that exists between Mansfield's life and problems at the time she was writing "The Man without a Temperament" and the events dealt with in the story.

1919

17 August Dr. Sorapure having advised K. M. not to enter a sanatorium, she decides to go to the Italian Riviera.

9 September Preparing to go away, K. M. writes an informal will-a letter to be left at the bank for Murry.

11 September K. M.'s longest stay in any one place since "Clovelly Mansions" comes to an end as Murry accompanies her and L.M. to San Remo, Italy. After settling them into the Casetta Deerholm, Ospedaletti, he returns to Hampstead.

12 November Harold Beauchamp, with his Roman Catholic cousin Connie Beauchamp (of Menton), visits K. M. at the Casetta.

21 November $\quad$ K. M. reviews Night and Day in the Athenaeum .

5 December Murry ably criticises the Georgian Poets in the Athenaeum .

16 December Disturbed by K. M.'s unhappy letters, Murry joins her at the Casetta (until 2 January 1920).

1920

5 January (The day after landing at Auckland, Harold Beauchamp marries Annie's closest friend, Mrs. Laura Bright).

11 January "The Man without a Temperament" written.

Two more interesting pieces of information in this narrative and biographic coincidences:(1) The protagonist of the short story is an editor ("By the way, Dennis, I picked up a very jolly little edition of ..." [Mansfield, "The Man without a Temperament" 170]). As we can see in the chronology, at the time Murry was the editor of Athenaeum, a literary journal; (2) At the end of the story, Mrs. Salesby calls her husband affectionately "Boogles." "Bogey" was Katherine Mansfield's name for John Middleton Murry (see Mansfield, Letters and Journals 143, 205). 